\title{
MICROPROPAGATION AND ACCLIMATIZATION OF Aegiphila verticillata Vell.: AN ENDANGERED WOODY SPECIES ${ }^{1}$
}

Luísa Maria Silveira de Almeida ${ }^{2}$, Leandro Elias Morais ${ }^{3}$, Cristiano Ferrara de Resende ${ }^{3}$, Virgínia

Fernandes Braga ${ }^{3}$, Paula da Fonseca Pereira ${ }^{3}$, Rodolpho Abrantes Camerini e Silva ${ }^{3}$ e Paulo Henrique

Pereira Peixoto ${ }^{4}$

\begin{abstract}
The objective of this work was to establish an efficient protocol for in vitro multiplication and rooting, as well as ex vitro acclimatization of Aegiphila verticillata, a woody species found in Brazilian rocky fields. Aseptic cultures were established by seeds and two multiplication analyses were performed. In the first, we employed 6-benzylaminopurine (BAP - 0, 2.5, 5 and 7.5 $\mu \mathrm{M}$ ) $+\alpha$-naphthalene acetic acid (NAA $-0,0.2,0.4$ and $0.6 \mu \mathrm{M})$ and, in the second, were studied adenine sulfate, kinetin and thidiazuron $(0,5$, $7.5,10$ and $12.5 \mu \mathrm{M})$. After 90 days, we assessed the quantitative and qualitative shoot propagation. There were more than $90 \%$ seed germination and low contamination (2\%). In multiplication phase, the culture medium that promoted the best quantitative and qualitative culture development was supplemented with $7.5 \mu \mathrm{M}$ BAP $+0.4 \mu \mathrm{M}$ NAA. In the rooting assay, were used NAA, indole-3-acetic acid (IAA) and indole-3-butyric acid (IBA) $(0,0.1,0.2,0.3$ or $0.4 \mu \mathrm{M})$. After 90 days, the root number and rooting quality were evaluated. In this analysis, differences were not found between the control and the other treatments. Rooted plantlets were acclimatized in styrofoam trays for 30 days, after which they were transferred to pots in the greenhouse. Only $3 \%$ of the plants subjected to initial acclimatization died and $70 \%$ of the plants transferred to the field conditions survived and showed normal development. The results founded in this work are the first involving in vitro propagation and ex vitro acclimatization of Aegiphila verticillata and provide a continuous supply of this medicinal native species, endangered due anthropogenic activities.
\end{abstract}

Keywords: In vitro propagation; Ex vitro culture; Rocky fields.

\section{MICROPROPAGAÇÃO E ACLIMATIZAÇÃO DE Aegiphila verticillata Vell.: UMA ESPÉCIE ARBÓREA AMEAÇADA DE EXTINÇÃO}

\begin{abstract}
RESUMO - Os objetivos deste trabalho foram estabelecer protocolos eficientes para a multiplicação $e$ enraizamento in vitro, bem como para a aclimatização ex vitro de Aegiphila verticillata, uma espécie arbórea típica dos campos rupestres brasileiros. Culturas assépticas foram estabelecidas a partir de sementes, $e$ dois experimentos de multiplicação foram realizados. No primeiro experimento, foram utilizados 6-benzilaminopurina $(B A P-0 ; 2,5 ; 5 ;$ e 7,5 $\mu M)+$ ácido $\alpha$-naftaleno acético (ANA - 0;0,2;0,4; e 0,6 $\mu M$ ) e, no segundo, sulfato de adenina, cinetina ou thidiazuron $(0 ; 5 ; 7,5 ; 10 ;$ e 12,5 $\mu \mathrm{M})$. Após 90 dias, foram avaliados $o$ número e a qualidade das brotações. Houve mais de $90 \%$ de germinação das sementes e reduzida taxa de contaminação (2\%). Na etapa de multiplicação, o meio que promoveu o melhor desenvolvimento qualitativo e quantitativo das culturas foi o suplementado com 7,5 $\mu \mathrm{M}$ de BAP $+0,4 \mu \mathrm{M}$ de ANA. No experimento de enraizamento, foram utilizados ANA, ácido indol acético (AIA) ou ácido indol butírico (AIB) $(0 ; 0,1 ; 0,2$; $0,3 ;$ e 0,4 $\mu \mathrm{M})$. Após 90 dias, foram avaliados o número de raízes e a qualidade do sistema radicular. Nessa análise, não foram encontradas diferenças entre o controle e os demais tratamentos. Plântulas enraizadas
\end{abstract}

\footnotetext{
${ }^{1}$ Recebido em 25.05.2013 aceito para publicação em 01.12.2014.

${ }^{2}$ Universidade Federal de Juiz de Fora, Graduando em Farmácia, Juiz de Fora, MG - Brasil. E-mail: <luisamsalmeida@yahoo.com.br>.

${ }^{3}$ Universidade Federal de Juiz de Fora, Graduando em Biologia, Juiz de Fora, MG - Brasil. E-mail: <leandroufjf@yahoo.com.br>, <cristianoig2004@hotmail.com>,<viplanta@yahoo.com.br>, <pauladafonsecapereira@yahoo.com.br>e <rodolphoabrantes@yahoo.com.br>.

${ }^{4}$ Universidade Federal de Juiz de Fora, Departamento de Botânica, ICB, Juiz de Fora, MG - Brasil. E-mail: <paulo.peixoto@ufjf.edu.br>.

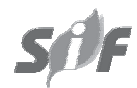

Revista Árvore, Viçosa-MG, v.39, n.2, p.305-314, 2015

http://dx.doi.org/10.1590/0100-67622015000200010
} 
foram aclimatizadas inicialmente por 30 dias em bandejas de isopor, período após o qual foram transferidas para vasos, em casa de vegetação. Apenas $3 \%$ das plantas submetidas à aclimatização inicial morreram, e $70 \%$ daquelas transferidas para a casa de vegetação sobreviveram e apresentaram desenvolvimento normal. Os resultados encontrados neste trabalho são os primeiros relatos envolvendo a propagação in vitro e a aclimatização ex vitro de Aegiphila verticillata e possibilitam o fornecimento de um suprimento contínuo dessa espécie medicinal nativa, ameaçada de extinção devido às atividades antrópicas.

Palavras-chave: Propagação in vitro; cultivo ex vitro; Campos rupestres.

\section{INTRODUCTION}

The anthropogenic perturbations in rocky fields have increased in recent years and the impacts of these events on plant populations is not-well known, especially on endemic species (GIULIETTI et al., 2000; VITTA, 2002). The Aegiphila verticillata Vell. (Lamiaceae) is a Brazilian Savanna (Cerrado) tree occurring in rocky compacted soil in areas located up to $900 \mathrm{~m}$. In the Serra do Cipó, MG, a typical rocky fields, this species present restricted occurrence and population decline as a result of tourism expansion, mining activities and, especially, by frequent wild fires due human activities (SALIMENA-PIRES; GIULIETTI, 1998).

Several species of Aegiphila Jacq. are recognized for their use in folk medicine, especially because of its action against the mosquito Aedes aegypti L. larvae (MENDONÇA et al., 2005) and in venomous snake bite treatments (LEITÃO et al., 1996). The Aegiphila Jacq. extracts have confirmed biological and pharmacological activity (COSTA-LOTUFO et al., 2004; LUCIANO et al., 2005). For medicinal plants, in vitro propagation allows the asexual reproduction of species with recognized production of active principles (DEBNATH et al., 2006). Cloning in vitro is particularly useful for the conservation of endangered species, propagation of recalcitrant genotypes and cultivation under controlled conditions, this allows the extraction and purification of active substances and their use in bioreactors systems and in chemistry biotransformation (PLETSCH, 1998). Micropropagation is particularly important for species that have very low germination and vegetative propagation rates, as observed for Aegiphila verticillata Vell. (WETZEL et al., 2003). Although there are several studies reporting procedures for micropropagation of native woody Cerrado species (SANTOS et al., 2006; SOARES et al., 2007; MARTINS et al., 2011; OLIVEIRA et al., 2011; PINHAL et al., 2011), to our knowledge, there have been no studies concerning species of the Aegiphila Jacq. genus.

Revista Árvore, Viçosa-MG, v.39, n.2, p.305-314, 2015
Since the native woody species have been successfully propagated by in vitro procedures (COUTO et al., 2004; RIBAS et al., 2005; GOMES et al., 2010), this study aimed to develop an efficient protocol for the establishment, multiplication and rooting of in vitro cultures, as well as the acclimatization of Aegiphila verticillata Vell. plantlets, in order to provide an alternative and continuous supply of this native medicinal species, which is endangered due to anthropogenic interferences.

\section{MATERIALAND METHODS}

\subsection{In vitro cultures establishment}

Cultures of $A$. verticillata Vell. were initially established in vitro from seeds collected in their natural habitat at Serra do Cipó, in Jaboticatubas city, MG, Brazil. The seeds were obtained from a single specimen, established under natural field conditions. The propagules were disinfested using commercial bleach with $2 \%$ (v/v) of active chlorine, at $30 \%$ (v/v), for $20 \mathrm{~min}$, under stirring. After rinsing them in distilled and autoclaved water, eighty seeds were aseptically inoculated using a laminar flow hood (VECO () in a $2.5 \times 15 \mathrm{~cm}$ test tube, containing $15 \mathrm{~mL}$ of $1 / 2$ MS medium (MURASHIGE; SKOOG, 1962), devoid of growth regulators. Sucrose $\left(30 \mathrm{~g} \mathrm{~L}^{-1}\right)$ and agar ( $\left.7 \mathrm{~g} \mathrm{~L}^{-1}\right)$ were supplied. The $\mathrm{pH}$ of culture medium was adjusted to $5.7 \pm 0.1$ before autoclaving, performed at $120^{\circ} \mathrm{C}$ and $1 \mathrm{~atm}$ pressure, for $20 \mathrm{~min}$. Afterwards, the test tubes were capped with autoclavable polyethylene closures and sealed with $15 \mu \mathrm{m}$ PVC film, stretchable and self-adhesive (Vitaspenser, Goodyear $\left.{ }^{\circledR}\right)$. After inoculation, the cultures were maintained for 40 days in a growth chamber at $25 \pm 5^{\circ} \mathrm{C}$, illuminated with fluorescent light bulbs of $40 \mathrm{~W}$ (white-cool/grolux, 1:1), with $45 \mu$ moles photons $\mathrm{m}^{-2} \mathrm{~s}^{-1}$ and a photoperiod of 16 hours.

\subsection{Multiplication phase}

In the multiplication stage, nodal segments were used with at least three internodes $( \pm 1.5 \mathrm{~cm})$, established

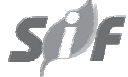


from seeds and previously maintained in vitro. In the first multiplication assay, the MS medium, added of $\operatorname{agar}\left(7 \mathrm{~g} \mathrm{~L}^{-1}\right)$ and sucrose $\left(30 \mathrm{~g} \mathrm{~L}^{-1}\right)$, was supplemented with 6-benzylaminopurine (BAP) at 0, 2.5, 5 and $7.5 \mu \mathrm{M}$, combined with $\alpha$-naphthalene-acetic acid (NAA) at $0,0.2,0.4$ and $0.6 \mu \mathrm{M}$, totaling 16 treatments, with 10 replicates each. In the second analysis, using the same basic medium as in the first study, we used adenine sulfate (AS), kinetin (KIN) and thidiazuron (TDZ) at 5, 7.5, 10 and $12.5 \mu \mathrm{M}$. The explants were horizontally inoculated in the culture medium in a laminar flow hood, and maintained in a growth room under the same conditions reported for the establishment of the cultures. After 90 days, the cultures were evaluated for the number of multiple shoots per explant. In parallel to obtain quantitative data, a qualitative analysis, at two steps were performed, the first, at 90 days, and the second, without subcultures, one year after the in vitro establishment. In these analyses, scores were assigned from 1 to 5, given in triplicate, independently by three different assessors, considering the quality of the shoots. The score of 5 represented shoots with high quality and score of 1 the worst quality.

\subsection{Rooting phase}

After performing the multiplication assay, the explants of A. verticillata Vell. were subjected to in vitro rooting study. The explants, consisting of an apical section with at least 3 internodes $( \pm 1.5 \mathrm{~cm})$ were vertically inoculated in MS medium, in full strength minerals and vitamins, with agar $\left(7 \mathrm{~g} \mathrm{~L}^{-1}\right)$ and sucrose (30 $\left.\mathrm{g} \mathrm{L}^{-1}\right)$, supplemented with NAA, indole-3 acetic acid (IAA) and indole-3 butyric acid (IBA) at 0.1, 0.2, 0.3 and $0.4 \mu \mathrm{M}$, beyond the control, totaling 13 treatments, with 10 replicates each. After in vitro inoculation, the cultures were transferred to a growth room and maintained under the same conditions reported above for multiplication phase. After 90 days, the experiments were quantitatively evaluated, considering the root number, and qualitatively, considering the quality of each explant, using the same criterion scores from 1 to 5 suggested in item 2.2.

\subsection{Acclimatization phase}

Plantlets from the rooting assay were acclimatized using the micro-cuttings technique (HARTMAN et al., 2002). After removal of the micro-cuttings from the test tubes and rinsing the root system with tap water to remove debris from the culture medium, the propagules were dipped in a solution of IBA $5 \mu \mathrm{M}$ for one minute. The rooted micro-cuttings were then planted in polystyrene trays of $16.5 \mathrm{~cm}$ x $50 \mathrm{~cm}$, with $128 \mathrm{cells}$, filled with substrate Plantmax Hortaliças HT®) (Eucatex Agro, Brazil) and covered with clear plastic, fully sealed, to maintain the moist environment inside of the test tubes. After 30 days, the plants were transferred to 5 L pots filled with substrate Plantmax Hortaliças HT® and maintained in the greenhouse under automatic micro-sprinkler irrigation, twice a day, for $5 \mathrm{~min}$. After three months, the plants were transferred to plant beds of $40 \times 40 \times 40 \mathrm{~cm}$, filled with soil:sand:cattle manure mix (in the ratio $3: 2: 1, \mathrm{v} / \mathrm{v} / \mathrm{v}$ ), without supplemental chemistry fertilization, and watered twice a week. After 2 years under field conditions, true type plants with $1.5 \mathrm{~m}$ height, in average, showed normal vegetative development, flowering and fructification.

\subsection{Statistical analysis}

All assays were conducted in a completely randomized scheme. The quantitative data obtained in the assays of in vitro rooting and multiplication were transformed by $\sqrt{x+1}$. The qualitative data obtained from the scores were converted to $\sqrt{x}$. After ANOVA, the averages were compared by the ScottKnott test at 5\% probability using the program SAEG (version 9.1).

\section{RESULTS}

\subsection{In vitro cultures establishment}

During the in vitro establishment, seeds and seedlings of $A$. verticillata Vell. were monitored regarding the fungal and bacterial contamination, as well as the seeds germination. The in vitro establishment from seeds was very successful with germination index over $90 \%$ and reduced contamination index (lower than $2 \%$ ).

\subsection{Multiplication phase}

After germination and stabilization of in vitro cultures, explants from micro-seedlings of $A$. verticillata Vell. were used in the first multiplication assay, performed in response to the BAP and NAA combination. The studies showed that in the absence of BAP, the increase in NAA concentration resulted in no significant changes in the number of shoots produced (Table 1).

Revista Árvore, Viçosa-MG, v.39, n.2, p.305-314, 2015 
Table 1 - Average number of apical shoots in explants of $A$. verticillata founded in vitro in response to different combinations of BAP and NAA ( ${ }^{1}$ Means followed by the same letter (in each line) are not significantly different by the ScottKnott test at $5 \%$ probability) and to different concentrations of AS, KIN and TDZ, 90 days after inoculation $\left({ }^{2}\right.$ Means followed by the same letter (in column) are not significantly different by the Scott-Knott test at $5 \%$ probability). Variation coefficient $=18 \% ; \mathrm{n}=10$

Tabela 1 - Número médio de brotações apicais em explantes de A. verticillata obtidos in vitro em resposta a diferentes combinações de BAP e ANA ( ${ }^{1}$ As médias seguidas pelas mesmas letras (em cada linha) não diferem significativamente entre si, pelo teste de Scott-Knott a 5\% de probabilidade) e a diferentes concentrações de SA, KIN e TDZ, 90 dias após a inoculação ( ${ }^{2}$ As médias seguidas pelas mesmas letras (na coluna) não diferem significativamente entre si, pelo teste de Scott-Knott a 5\% de probabilidade). Coeficiente de variação = 18\%; $n=10$

\begin{tabular}{ccccccccc}
\hline \multirow{2}{*}{ BAP $(\mu \mathrm{M})$} & \multicolumn{9}{c}{ NAA $(\mu \mathrm{M})$} & $(\mu \mathrm{M})$ & AS & KIN & TDZ \\
\cline { 2 - 5 } 0 & 0 & 0,2 & 0,4 & 0,6 & 0 & $5,65 \mathrm{~b}^{2}$ & $5,65 \mathrm{~b}$ & $5,65 \mathrm{~b}$ \\
2,5 & $11,69 \mathrm{a}^{1}$ & $5,55 \mathrm{a}$ & $9,45 \mathrm{a}$ & $10,15 \mathrm{a}$ & 5 & $5,32 \mathrm{~b}$ & $5,27 \mathrm{~b}$ & $7,98 \mathrm{a}$ \\
5 & $13,29 \mathrm{a}$ & $17,83 \mathrm{a}$ & $17,80 \mathrm{a}$ & $12,04 \mathrm{a}$ & 7,5 & $7,00 \mathrm{~b}$ & $11,37 \mathrm{a}$ & $7,98 \mathrm{a}$ \\
7,5 & $12,73 \mathrm{a}$ & $14,87 \mathrm{a}$ & $16,76 \mathrm{a}$ & $10,74 \mathrm{a}$ & 10 & $6,65 \mathrm{~b}$ & $9,05 \mathrm{a}$ & $8,24 \mathrm{a}$ \\
\hline
\end{tabular}

Similar responses were found in the presence of 2.5 and $5 \mu \mathrm{M}$ BAP. However, at $7.5 \mu \mathrm{M}$ BAP, NAA addition to the culture medium increased the number of shoots produced. A massive shoot proliferation was observed in the presence of $7.5 \mu \mathrm{M}$ BAP and $0.4 \mu \mathrm{M}$ NAA, with 26.7 apical shoots per explant. In this treatment, the amount of new formed shoots was $129 \%$ higher than that found in the control and $274 \%$ higher than in presence of $7.5 \mu \mathrm{M}$ BAP alone, demonstrating the importance of this auxin in the cultivation of in vitro proliferation of this species. The Figure $1 \mathrm{~A}$ illustrates the multiplication phase results in response to BAP and NAA.

The qualitative analysis concerning the in vitro multiplication established the best results in response to a combination of $7.5 \mu \mathrm{M}$ BAP and $0.4 \mu \mathrm{M}$ NAA, corresponding to the same treatment found as the best in quantitative analysis (Table 2).

In the second multiplication assay, assessing the effects of different cytokinins on in vitro propagation of $A$. verticillata Vell., was observed that the increase in the concentration of AS did not result in improving in the shoot multiplication (Table 1). However, significant differences were found for the other cytokinins. To KIN, stimuli on multiplication were observed from $7.5 \mu \mathrm{M}$. The addition of TDZ also stimulated the shoots proliferation compared to control, but no significant differences among the concentrations were found. The most important results regarding the multiplication phase of A. verticillata Vell. were found in cultures maintained in media supplemented with $7.5 \mu \mathrm{M} \mathrm{KIN}$, although they did not differ from those obtained in response to higher doses of this growth regulator and also those found in the response to TDZ (Figure 1B). Despite to the results, neither of the treatments with these cytokinins alone, produced more shoot proliferation that the combination of $7.5 \mu \mathrm{M}$ BAP $+0.4 \mu \mathrm{M}$ NAA.

In the first qualitative analysis from the multiplication, performed 90 days after the in vitro inoculation (Table 2), we found as the best treatments $7.5 \mu \mathrm{M} \mathrm{KIN}, 10 \mu \mathrm{M}$ KIN, and $5 \mu \mathrm{M}$ TDZ. However, in the second analysis, carried out after one year of in vitro growth, although the cultures have maintained the multiplying ability, differences between the treatments were no longer observed (data not shown).

\subsection{Rooting phase}

Regarding of the root number, in this study we found no significant differences in response to NAA, IAA or IBA (Table 3). The best micro-cuttings rooting were observed in response to $0.3 \mu \mathrm{M}$ NAA and to $0.1 \mu \mathrm{M}$ IAA. From this IAA concentration and in every one of the IBA concentrations, a callus development on the shoot bases were observed, whereas, in contrast, none found in any of the NAA concentrations (Figure 1C). In general, the amount of developed roots was low. In the qualitative analysis performed on the tissues subjected to rooting, it was found the treatments containing NAA had the best result, due to no callus formation on the micro-cutting bases (Table 3 ).

Since the rooting found in the presence of the IAA and IBA were low and due to their stimulus on

Revista Árvore, Viçosa-MG, v.39, n.2, p.305-314, 2015

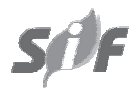



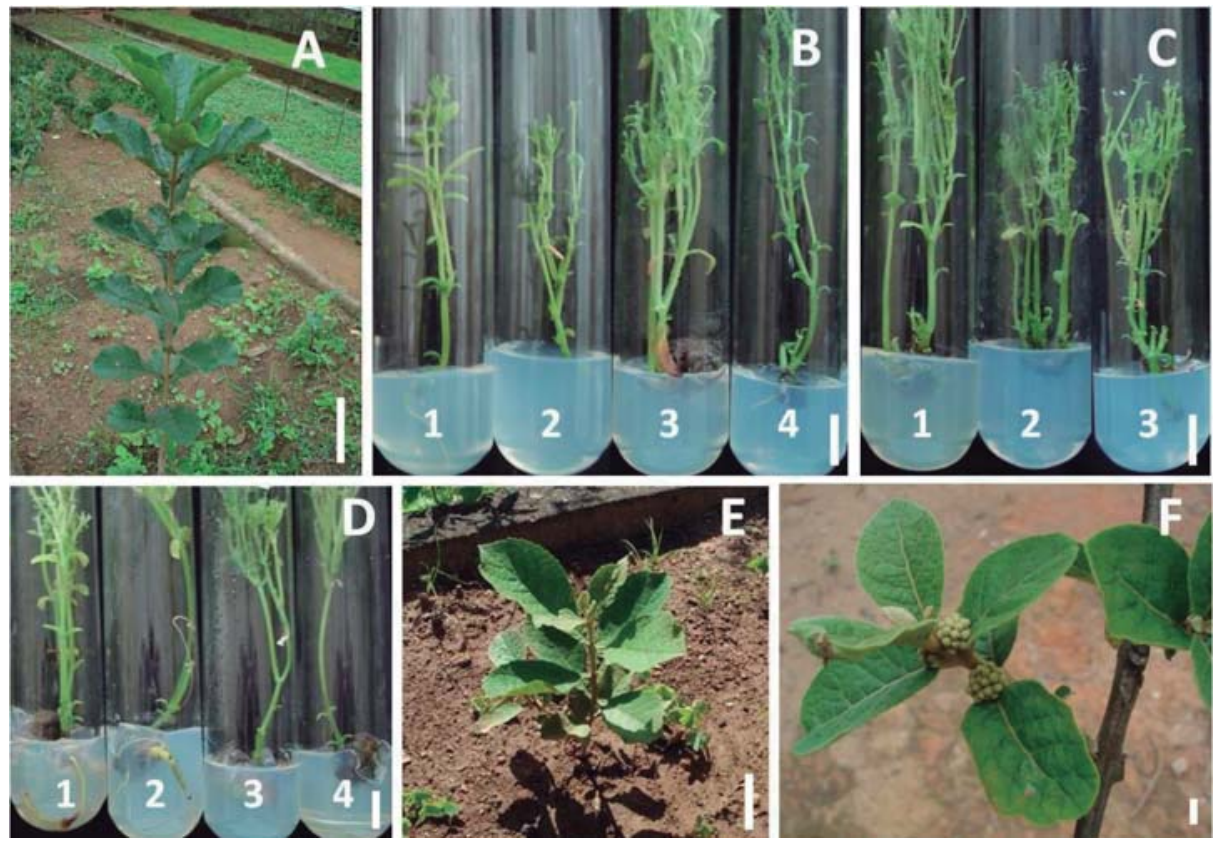

Figure 1 - Plants of A. verticillata in the field conditions, 1.5 years (A) and 90 days (E) after acclimatization (scale bar $=10 \mathrm{~cm})$. Detail of fruits in early phase of development $(\mathrm{F})(\mathrm{scale} b \mathrm{bar}=1 \mathrm{~cm})$. Cultures in the multiplication medium in response to BAP + NAA $(\mu \mathrm{M})(1=7.5+0.0 ; 2=7.5+0.2 ; 3=7.5+0.4 ; 4=7.5+0.6), 90$ days after inoculation $(\mathrm{C})$, and to different concentrations of $\mathrm{AS}(1=7.5 \mu \mathrm{M}), \mathrm{KIN}(2=7.5 \mu \mathrm{M})$ and TDZ $(3=$ $5 \mu \mathrm{M}$ ), one year after in vitro inoculation (B); cultures in rooting medium in the presence of different concentrations of IAA and IBA, after 90 days of in vitro inoculation (D) $($ scale bar $=1 \mathrm{~cm})$.

Figura 1 - Plantas de A. verticillata em condições de campo, 1,5 ano (A) e 90 dias (E) após a aclimatização (escala $=10 \mathrm{~cm})$. Detalhes de frutos na fase inicial de desenvolvimento $(\mathrm{F})($ escala $=1 \mathrm{~cm})$. Culturas em meio de multiplicação em resposta ao BAP + ANA $(\mu M)(1=7,5+0.0 ; 2=7,5+0.2 ; 3=7,5+0,4 ; 4=7,5+0,6) ;$ e 90 dias após a inoculação $(C)$, e a diferentes concentrações de SA $(1=7,5 \mu M), K I N(2=7,5 \mu M)$ e TDZ $(3=5 \mu M)$, um ano após a inoculação in vitro (B); culturas em meio de enraizamento em presença de diferentes concentrações de AIA e AIB, 90 dias após a inoculação in vitro $(D)($ escala $=1 \mathrm{~cm})$.

Table 2 - Qualitative analyses (1-5*) for in vitro multiplication of A. verticillata cultures in response to different combinations of BAP and NAA ( ${ }^{1}$ Means followed by the same letter (in each line) are not significantly different by the ScottKnott test at 5\% probability) and to different concentrations of AS, KIN and TDZ, 90 days after inoculation $\left({ }^{2}\right.$ Means followed by the same letter (in column) are not significantly different by the Scott-Knott test at 5\% probability). ${ }^{*}$ Score 5 represents the best quality of shoots and score 1 the worst quality. Variation coefficient $=12 \% ; \mathrm{n}=10$

Tabela 2 - Análise qualitativa (1-5*) da multiplicação in vitro de culturas de A. verticillata em resposta a diferentes combinações de BAP e ANA ( ${ }^{1}$ As médias seguidas pelas mesmas letras (em cada linha) não diferem significativamente entre si, pelo teste de Scott-Knott a 5\% de probabilidade), e a diferentes concentrações de SA KIN e TDZ, 90 dias após a inoculação $\left({ }^{2}\right.$ As médias seguidas pelas mesmas letras (na coluna) não diferem significativamente entre si, pelo teste de Scott-Knott a 5\% de probabilidade). *A nota 5 representa a melhor qualidade das brotações e a nota 1, a pior qualidade. Coeficiente de Variação $=12 \% ; n=10$.

\begin{tabular}{|c|c|c|c|c|c|c|c|c|}
\hline \multirow{2}{*}{$\mathrm{BAP}(\mu \mathrm{M})$} & \multicolumn{4}{|c|}{ NAA $(\mu \mathrm{M})$} & \multirow{2}{*}{$\begin{array}{c}(\mu \mathrm{M}) \\
0\end{array}$} & \multirow{2}{*}{$\begin{array}{c}\text { AS } \\
1,66 \mathrm{~d} 2\end{array}$} & \multirow{2}{*}{$\begin{array}{c}\mathrm{KIN} \\
1,66 \mathrm{~d}\end{array}$} & \multirow{2}{*}{$\begin{array}{c}\text { TDZ } \\
1,66 \mathrm{~d}\end{array}$} \\
\hline & 0 & 0,2 & 0,4 & 0,6 & & & & \\
\hline 0 & 2,59 a 1 & $1,00 \mathrm{~b}$ & $3,00 \mathrm{a}$ & $2,94 \mathrm{a}$ & 5 & $3,33 \mathrm{~b}$ & $1,82 \mathrm{~d}$ & $5,00 \mathrm{a}$ \\
\hline 2,5 & $1,91 \mathrm{~b}$ & $3,00 \mathrm{~b}$ & $4,65 \mathrm{a}$ & 3,83 a & 7,5 & $2,16 \mathrm{c}$ & $4,66 \mathrm{a}$ & $3,83 \mathrm{~b}$ \\
\hline 5 & $3,65 \mathrm{a}$ & $3,81 \mathrm{a}$ & $4,28 \mathrm{a}$ & $3,61 \mathrm{a}$ & 10 & $3,33 \mathrm{~b}$ & $4,65 \mathrm{a}$ & $3,81 \mathrm{~b}$ \\
\hline 7,5 & $2,16 \mathrm{~b}$ & $1,82 \mathrm{~b}$ & $5,00 \mathrm{a}$ & 3,49 a & 12,5 & $2,50 \mathrm{c}$ & $3,83 \mathrm{~b}$ & $4,00 \mathrm{~b}$ \\
\hline
\end{tabular}


Table 3 - Average number of roots and qualitative analyses of rooted explants of A. verticillata founded in vitro in response to different auxins, 90 days after inoculation. ${ }^{1}$ Means followed by the same letter are not significantly different by the Scott-Knott test at $5 \%$ probability. Variation coefficient $=\mathrm{VC} ; \mathrm{n}=10$

Tabela 3 - Número médio de raízes e análise qualitativa do enraizamento em explantes de $\mathbf{A}$. verticillata obtidos in vitro em resposta a diferentes auxinas, 90 dias após a inoculação. ${ }^{1}$ As médias seguidas pelas mesmas letras não diferem significativamente entre si, pelo teste de Scott-Knott a 5\% de probabilidade. Coeficiente de variação = VC; $n=10$.

\begin{tabular}{ccccc}
\hline \multicolumn{2}{c}{ Growth regulator $(\mu \mathrm{M})$} & $\begin{array}{c}\text { Number of roots/explant } \\
(\mathrm{VC}=15 \%)\end{array}$ & $\begin{array}{c}\text { Quality of rooted explants } \\
(\mathrm{VC}=10 \%)\end{array}$ \\
\hline NAA & IAA & IBA & & $4.65 \mathrm{a}^{1}$ \\
0 & 0 & 0 & $0.27 \mathrm{a}^{1}$ & $3.32 \mathrm{a}$ \\
0.1 & - & - & $0.61 \mathrm{a}$ & $3.49 \mathrm{a}$ \\
0.2 & - & - & $0.61 \mathrm{a}$ & $4.16 \mathrm{a}$ \\
0.3 & - & - & $1.30 \mathrm{a}$ & $4.16 \mathrm{a}$ \\
0.4 & - & - & $1.00 \mathrm{a}$ & $3.61 \mathrm{a}$ \\
- & 0.1 & - & $1.30 \mathrm{a}$ & $2.77 \mathrm{~b}$ \\
- & 0.2 & - & $0.27 \mathrm{a}$ & $2.85 \mathrm{~b}$ \\
- & 0.3 & - & $0.61 \mathrm{a}$ & $1.29 \mathrm{c}$ \\
- & 0.4 & - & $0.61 \mathrm{a}$ & $2.31 \mathrm{~b}$ \\
- & - & 0.1 & $0.61 \mathrm{a}$ & $1.00 \mathrm{c}$ \\
- & - & 0.2 & $0.00 \mathrm{a}$ & $1.00 \mathrm{c}$ \\
- & - & 0.3 & $0.27 \mathrm{a}$ & $1.15 \mathrm{c}$ \\
\hline
\end{tabular}

callus formation, these auxins were deemed unsuitable for the in vitro rooting of the A. verticillata Vell. Due to reduced rooting of the explants even in the response to NAA, we decided to perform another assay with this auxin in a range slightly higher. However, this analysis also no found significant differences between the treatments, although, qualitatively, there was a slight improvement in the rooting of the explants maintained at higher concentrations of NAA (data not shown).

\subsection{Acclimatization phase}

After the acclimatization in ex vitro conditions, the A. verticillata Vell. plantlets showed only $3.33 \%$ mortality. After 30 days, the trays were moved to a greenhouse, and kept under an automatic micro-sprinkler irrigation system. From the all, the plants transferred to this environment, $70 \%$ of them survived and were efficiently transplanted to plant beds (Figure 1D). After two years under field conditions, true type plants with $1.5 \mathrm{~m}$ height, on average, showing typical vegetative development, flowering and fructification (Figure 1E).

\section{DISCUSSION}

The low contamination levels (lower than $2 \%$ ) and the germination success (over 90\%) demonstrated the efficiency of disinfection procedures and the in vitro germination capacity described in this study, since the maximum acceptable contamination is $10 \%$ (HARTMAN et al., 2002; GEORGE, 1993). Although there is a report of success with the Aegiphila verticillata Vell. seeds using the in vitro cryopreservation (WETZEL et al., 2003), this method does not allow obtaining the high propagation rates, which were obtained in response to the in vitro culture.

The addition of NAA in the culture medium containing $7.5 \mu \mathrm{M}$ BAP was responsible for the significant increase in the number of shoots produced during the multiplication phase. Similar results were found for the in vitro cultures of the Coleus forskohlii (Willd.) Briq., another Lamiaceae, which increases in the frequency of regeneration and in the shoot production, which were obtained in response to the addition of $4.6 \mu \mathrm{MKIN}+0.5 \mu \mathrm{MNAA}$ in the culture medium (REDDY et al., 2001). In contrast, the supply of this auxin reduced the in vitro shoot formation in the Ocimum gratissimum L., another Lamiaceae (SAHA et al., 2012).

In the second multiplication assay, which evaluated the effects of the different cytokinins on in vitro propagation of the A. verticillata Vell., any treatment was more efficient than the combination of $7.5 \mu \mathrm{M}$ BAP $+0.4 \mu \mathrm{M}$ NAA. Specific responses related to the in vitro shoot multiplication from another Lamiaceae

Revista Árvore, Viçosa-MG, v.39, n.2, p.305-314, 2015 
are found in literature. In the Pogostemon cablin (Blanco) Benth., 2.2 $\mu \mathrm{M}$ BAP was more efficient than KIN, resulting in an increase in shoot multiplication (SWAMY et al., 2010). However, higher KIN concentrations resulted in the reduction in the shoot propagation, which was also found from Ocimum basilicum L. grown in BAP concentrations above 1.1 $\mu \mathrm{M}$ (SAHOO et al., 1997). For Ocimum gratissimum L., 4.4 $\mu \mathrm{MBAP}$ was also more efficient than KIN (SAHA et al., 2012). In contrast to the results found in this study, for those species, the addition of auxins (NAA or IBA) to the culture media supplied with the best BAP concentrations caused no benefits during the in vitro multiplication phase. Reddy et al. (2001) also found the best results in the propagation of the Coleus forskohlii (Willd.) Briq. with the use of $4.6 \mu \mathrm{M}$ KIN, instead of in the same concentrations of BAP or TDZ. As in this study, these authors found advantages in supplying auxin at a lower concentration $(0.5 \mu \mathrm{M}$ NAA), with the formation of longer shoots and increased numbers. For the Mentha $x$ gracilis Sole, however, $2 \mu \mathrm{M}$ TDZ showed more improved efficiency than the BAP and KIN at the same concentrations, with higher numbers of shoots as well as higher nodal segments per shoots (GARLET et al., 2011). These results found in the literature demonstrate that there is a variety of responses for the use of different cytokinins on in vitro culture of Lamiaceae.

The results of the second qualitative analysis, carried out after one year of in vitro growth, demonstrated that $A$. verticillata Vell. could be maintained in in vitro germplasm banks for a prolonged time and showed a long-term proliferative capacity (Figure 1B). This long-term maintenance also allowed observing that the cultures maintained with TDZ, exhibit hyperhydricity and precocious senescence, which, in literature, is frequently assigned to the effects of this strong cytokinin (LU, 1993; KADOTA; NIIMI, 2003; IVANOVA; van STANDEN, 2011; AHMED; ANIS, 2012).

In this study, we found no significant differences in the number of roots between treatments containing different auxins and the control, although, in literature, the in vitro rooting is most often observed in response to exogenous auxins. Several studies indicate efficient rooting in the culture medium free of these growth regulators to some Lamiaceae. In the Lavandula pedunculata Cav., rooting was affected from the BAP present in the previous culture, being above $70 \%$ in the plants grown in a culture medium without this cytokinin (ZUZARTE et al., 2010). In Pogostemon cablin (Blanco) Benth., auxins caused a reduction in the rooting and stimulus for the callus formation, showing no positive effects in the number and elongation of roots (SWAMY et al., 2010). For Coleus forskohlii (Willd.) Briq., the supply of auxins (IAA or IBA) resulted in reductions in rooting when compared to control, without growth regulations (REDDY et al., 2001). For this species, the use of IAA, regardless of the concentration, and IBA, at high concentrations, induced calluses and nonstimulated root formation. According Juliani JR. et al. (1999), shoots containing high endogenous levels of auxin, when cultured in the presence of those growth regulators, showed rooting inhibition, resulting in stimulus to the callus formation on micro-cutting bases.

Although it was observed that the addition of NAA inhibited the root formations in the Ocimum basilicum L. (DODE et al., 2003), Sahoo et al. (1997) did not found rooting for this species in culture medium without auxins. These authors also reported the benefit of using high IBA concentrations $(4.9 \mu \mathrm{M})$, although the use of NAA, even at a lower concentration $(2.5 \mu \mathrm{M})$, has caused callus formation on micro-cutting bases. In the Ocimum gratissimum L., rooting induction was not observed in the medium without auxins, as well as those added to different NAA concentrations (2.5 to $10 \mu \mathrm{M})$ (SAHA et al., 2012). There was only suitable rooting in the medium supplemented with high IBA and IAA concentrations. In turn, Silva et al. (2006) reported that the use of $0.5 \mu \mathrm{M}$ IAA was effective not only for rooting, but also for the in vitro multiplication of the Melissa officinalis L., providing to the formation of a higher number of nodes per explant than on BAP or KIN medium supplied. Furthermore, the use of NAA did not allow rooting. The results from all these studies with other Lamiaceae demonstrate the response specificity among genotypes, indicating the need for adjustments of in vitro protocols and methodologies for each species.

\section{CONCLUSION}

Cultures of the A. verticillata Vell. were efficiently propagated in vitro in response to the $7.5 \mu \mathrm{M}$ BAP and $0.4 \mu \mathrm{M}$ NAA combination. Explants were maintained in vitro for up to 1 year without sub-culturing, which evidence the maintenance of the morphogenetic capacity and reduced explants senescence. The in vitro rooting 
was reduced, regardless of the auxin added. However, this species could be efficiently acclimatized to field conditions. This is the first paper that addresses the in vitro propagation of $A$. verticillata Vell. and the results showed that this system is an important tool for the propagation and conservation of their germplasm, contributing to advances in reproductive efficiency and in reduction of the extinction risk due the human activities in their natural environment.

\section{ACKNOWLEDGEMENT}

To the Fundação de Amparo à Pesquisa do Estado de Minas Gerais (FAPEMIG) and Programas de Apoio à Publicação/Pró-Reitorias de Pesquisa (PROPESQ) e Pós-gradução (PROPG)/Universidade Federal de Juiz de Fora (UFJF) for financial support for the development and publication of this work.

\section{REFERENCES}

AHMED, M. R.; ANIS, M. Role of TDZ in the quick regeneration of multiple shoots from nodal explant of Vitex trifolia L. - an important medicinal plant. Applied Biochemistry and Biotechnology, v.168, n.5, p.957-966, 2012.

COSTA-LOTUFO, L. V.; SILVEIRA, E. R.; BARROS, M. C. P.; LIMA, M.A. S.; MORAES, M. E. A.; MORAES,

M. O.; PESSOA, C. Antiproliferative effects of abietane diterpenes from Aegiphila lhotzkiana. Planta Medica, v.70, n.2, p.180-182, 2004.

COUTO, J. M. F.; OTONI, W. C.; PINHEIRO, A. L.; FONSECA, E. P. Desinfestação e germinação in vitro de sementes de mogno (Swietenia macrophylla King). Revista Árvore, v.28, n.5, p.633-642, 2004.

DEBNATH, M.; MALIK, C. P.; BISEN, P. S. Micropropagation: a tool for the production of high quality plant-based medicines. Current

Pharmaceutical Biotechnology, v.7, n.1, p.33-49, 2006.

DODE, L. B.; BOBROWSKI, V. L.; BRAGA, E. J. B.; SEIXAS, F. K.; SCHUCH, M. W. In vitro propagation of Ocimum basilicum L. (Lamiaceae). Acta Scientiarum Biological Sciences, v.25, n.2, p.435-437, 2003.

GARLET, T. M. B.; FLORES, R.; MESSCHMIDT, A. A. Influência de citocininas na micropropagação de Mentha x gracilis Sole.
Revista Brasileira de Plantas

Medicinais, v.13, n.1, p.30-34, 2011.

GEORGE, E. F. Plant propagation by tissue culture - Part 1: The technology. 2nd.ed. Exectics, 1993. 574 p.

GIULIETTI, A. M.; HARLEY, R. M.; QUEIROZ, L. P.; WANDERLEY, M. G. L.; PIRANI, J. R. Caracterização e endemismo nos Campos Rupestres da Cadeia do Espinhaço. In: CAVALCANTI, T. B.; WALTER, B. M. T. (Ed.). Tópicos atuais de botânica. Brasília: Embrapa Recursos Genéticos, 2000. p.311-318.

GOMES, G. A. C.; PAIVA, R.; HERRERA, R. C.; PAIVA, P. D. O. Micropropagation of Maclura tinctoria L.: an endangered woody species. Revista Árvore, v.34, n.1, p.25-30, 2010.

HARTMANN, H. T.; KESTER, D. E.; DAVIES JUNIOR, F. T.; GENEVE, R. L. Plant propagation: principles and pratices. 7.ed. New Jersey: Prentice Hall, 2002. 880p.

IVANOVA, M.; van STANDEN, J. Influence of gelling agent and cytokinins on the control of hypehydricity in Aloe polyphylla. Plant Cell, Tissue and Organ Culture, v.104, n.1, p.13-21, 2011.

JULIANI Jr., H. R.; KOROCH, A. R.; JULIANI, H. R; TRIPI, V. S. Micropropagation of Lippia junelliana (Mold.) Tronc. Plant Cell, Tissue and Organ Culture, v.59, n.3, p.175-179, 1999.

KADOTA, M.; NIIMI, Y. Effects of cytokinin types and their concentrations on shoot proliferation and hyperhydricity in in vitro pear cultivar shoots. Plant Cell, Tissue and Organ Culture, v.72, n.3, p.261-265, 2003.

LEITAO, S. G.; SILVA, M. H.; KAPLAN, M. A. C.; DELLE MONACHE, F. Constituents of some Aegiphila species and neutralization of Crotalus durissus terrificus venom by Aegiphila lhotzkyana. Fitoterapia, v. 67, n. 4, p. 377-379, 1996.

LU, C-Y. The use of thidiazuron in tissue culture. In Vitro Cellular and Developmental Biology - Plant, v.29, n.2, p.92-96, 1993. 
LUCIANO, J. H. S.; BARROS, M. C. P.; LIMA, M. A. S.; NASCIMENTO, R. F.; SILVEIRA, E. R. Volatile composition of leaves from Aegiphila lhotzkiana Cham. Flavour and Fragrance Journal, v.20, n.5, p.537-538, 2005.

MARTINS, L. M.; PEREIRA, A. M. S.; FRANÇA, S. C.; BERTONI, B. W. Micropropagação e conservação de Macrosyphonia velame (St. Hil.) Muell. Arg. em banco de germoplasma in vitro. Ciência Rural, v.41, n.3, p.454-458, 2011.

MENDONÇA, F. A. C.; SILVA, K. F.; SANTOS, K. K.; RIBEIRO JÚNIOR, K. A.; SANT'ANA, A. E. Activities of some Brazilian plants against larvae of the mosquito Aedes aegypti. Fitoterapia, v.76, n.7-8, p.629-636, 2005.

MURASHIGE, T.; SKOOG, F. A revised medium for rapid growth and bioassay with tobacco tissue culture. Physiologia Plantarum, v. 15, n.3, p.473-497, 1962.

OLIVEIRA, T. G.; PINA, P. S. S.; BERTONI, B. W.; FRANÇA, S. C.; PEREIRA, A. M. S.

Micropropagação de Croton antisyphiliticus Mart. Ciência Rural, v.41, n.10, p.1712-1718, 2011.

PINHAL, H. F.; ANASTÁCIO, M. R.; CARNEIRO, P. A. P.; SILVA, V. J.; MORAIS, T. P. ; LUZ, J. M. Q. Aplicações da cultura de tecidos vegetais em fruteiras do Cerrado. Ciência Rural, v.41, n.7, p.1136-1142, 2011.

PLETSCH, M. Compostos naturais biologicamente ativos. Biotecnologia Ciência $\&$

Desenvolvimento, v.4, p.12-15, 1998.

REDDY, P. S.; RODRIGUES, R.; RAJASEKHARAN, $\mathrm{R}$. Shoot organogenesis and mass propagation of Coleus forskohlii from leaf derived callus. Plant Cell, Tissue and Organ Culture, v.66, n.3, p.183-188, 2001.

\section{RIBAS, L. L. F.; ZANETTE, F.; KULCHETSCKI,} L.; GUERRA, M. P. Micropropagação de Aspidosperma polyneuron (peroba-rosa) a partir de segmentos nodais de mudas juvenis. Revista Árvore, v.29, n.4, p.517-524, 2005.

SAHA, S.; KADER, A.; SENGUPTA, C.; GHOSH, $\mathrm{P}$. In vitro propagation of Ocimum gratissimum $\mathrm{L}$. (Lamiaceae) and its evaluation of genetic fidelity using RAPD marker. American Journal of Biological Sciences, v.3, n.1, p.64-74, 2012.

SAHOO, Y.; PATTNAIK, S. K.; CHAND, P. K. In vitro clonal propagation of an aromatic medicinal herb Ocimum basilicum L. (sweet basil) by axillary shoot proliferation. In Vitro Cellular and Developmental Biology - Plant, v.33, n.4, p.293-296, 1997.

SALIMENA-PIRES, F. R.; GIULIETTI, A. M. Flora da Serra do Cipó, Minas Gerais: Verbenaceae. Boletim de Botânica da Universidade de São Paulo, v.17, p.155-186, 1998.

SANTOS, B. R.; PAIVA, R.; NOGUEIRA, R. C.; OLIVEIRA, L. M.; SILVA, D. P. C.; MARTINOTTO, C.; SOARES, F. P.; PAIVA. P. D. O.

Micropropagação de pequizeiro (Caryocar brasiliense Camb.). Revista Brasileira de Fruticultura, v.28, n.2, p.293-296, 2006.

SILVA, S.; LAGE, C. L. S.; ESQUIBEL, M. A.; GIL, R. A. S. S.; SATO, A. In vitro propagation of Melissa officinalis L. and production of essential oil. Plant Cell Culture \& Micropropagation, v.2, n.2, p.53-60, 2006.

SOARES, F. P.; PAIVA, R.; ALVARENGA, A. A.; NOGUEIRA, R. C.; EMRICH, E. B.;

MARTINOTTO, C. Organogênese direta em explantes caulinares de mangabeira (Hancornia speciosa Gomes). Ciência e

Agrotecnologia, v.31, n.4, p.1048-1053, 2007.

SWAMY, M. K.; BALASUBRAMANYA, S.; ANURADHA, M. In vitro multiplication of Pogostemon cablin Benth. through direct regeneration. African Journal of Biotechnology, v.9, n.14, p.2069-2075, 2010.

VITTA, F. A. Diversidade e conservação da flora nos Campos Rupestres da Cadeia do Espinhaço em Minas Gerais. In: Biodiversidade, conservação e uso sustentável da flora do Brasil. Recife: UFRPE, SBB, 2002. p.90-94.

WETZEL, M. M. V. S.; REIS, R. B.; RAMOS, K. $M$. Metodologia para criopreservação de sementes de espécies florestais nativas. Brasília, DF: Embrapa Recursos Genéticos e Biotecnologia, 2003. 5p. (Embrapa Recursos Genéticos e Biotecnologia. Circular Técnica, 26).

Revista Árvore, Viçosa-MG, v.39, n.2, p.305-314, 2015 
ZUZARTE, M. R.; DINIS, A. M.; CAVALEIRO, C.; SALGUEIRO, L. R.; CANHOTO, J. M. Trichomes, essential oils and in vitro propagation of
Lavandula pedunculata (Lamiaceae).

Industrial Crops and Products, v.32, n.3, p.580-587, 2010 . 